\title{
The Organizational Culture Audit: Countering Cultural Ambiguity in the Service Context
}

\author{
Mark R. Testa, Lori J. Sipe \\ San Diego State University, San Diego, USA \\ Email: mtesta@mail.sdsu.edu, lsipe@mail.sdsu.edu
}

Received January $11^{\text {th }}, 2013$; revised February $7^{\text {th }}$, 2013; accepted May $10^{\text {th }}, 2013$

\begin{abstract}
Copyright (C) 2013 Mark R. Testa, Lori J. Sipe. This is an open access article distributed under the Creative Commons Attribution License, which permits unrestricted use, distribution, and reproduction in any medium, provided the original work is properly cited.
\end{abstract}

\begin{abstract}
Development of a compelling organizational culture continues to be an imperative for organizations seeking a competitive advantage. Identifying culture deficiencies or gaps is an important step in creating such a culture. For culture development efforts to be successful, leaders must first know the reality of the current organizational culture, however assessing the organizations' true culture may be more complicated than it appears. Several theoretical frameworks illustrate how highly committed mangers may have difficulty in this regard. The following study links theory with application providing an action research based model of culture assessment. First, the rationale and conceptual model of cultural analysis is provided based on past research. Next, a five-step model analyzing ten cultural areas is proposed, and recommendations are provided for implementation.
\end{abstract}

Keywords: Organizational Culture; Leadership; Culture Assessment; Gap Analysis

\section{Introduction}

As competition increases and customers become more demanding, organizational leaders are faced with the dilemma of creating a sustainable competitive advantage. One method of developing such an advantage is to actively build a compelling organizational culture. This may particularly true in organizations where stakeholders deal directly with customers. This is well known by leading organizations with rich organizational cultures such as Southwest Airlines, Starbucks and Ritz Carlton, and is supported by some forty years of research (Schein, 1992). Whether termed "corporate" or "organizational" culture, the construct has become a mainstay variable in investigations of organizational development (Leidner \& Kayworth, 2006; Schein, 2004; Trefry, 2006).

Past studies have looked extensively at the relationship between culture and important organizational variables including organizational performance (Kotter \& Heskett, 1992; LeBlanc \& Mills, 1995; Xenikou \& Simosi, 2006), effectiveness (Denison \& Mishra, 1995; Kemp \& Dwyer, 2001), and profitability (Tidball, 1988). In organizations that provide services, customer perceptions are critical for success and culture may be an even more important variable as it has been linked to work-related attitudes (Bimbaum \& Sommers, 1986), and can influence individual and group behavior (Trefry, 2006). In the service setting, leaders do not have direct control over customer perceptions of quality or employee behavior (Ueno, 2010). Consequently, creating a compelling service-oriented culture may be one of the few organization influence tactics available for senior managers.

In spite of the importance of an organization's culture on essential outcomes, disconnects between the desired and actual culture may be occurring often. Mainstream examples of cultural disparity abound with problem companies such as Enron, BP and Home Depot. In these troubled organizations, espoused values were in direct conflict with actual organizational practices. Such dissonance may not lead to complete organizational failure to be worth note. Indeed, disconnects may be more subtle. For example, behavioral standards may not be practiced thoroughly by employees when management "talks-up" the importance of customer service, but does not role model the behavior. Morale may be reduced as management decisions conflict with espoused organizational values. The airline segment provides a good example as major carriers claim the importance of customer satisfaction, yet consistently rate lowest on factors important to customers (American Customer Satisfaction Index, 2011). Conversely, Southwest Airlines, which credits its culture to much of its success (Freiberg \& Freiberg, 1997), recently scored satisfaction ratings 17 points higher than the balance of the industry. In a recent survey in the hotel segment, some $78 \%$ of employees felt that their organization was committed to service quality (Savitt, 2012). At the same time, only 56\% of these employees felt that their organization's administrative policies and practices promoted the most effective service quality.

There are several potential reasons for a disparity in organizational culture perceptions. First, organizational culture is not a completely objective concept. Indeed, components of an organization's culture may be evaluated by different people in very different ways (Reichers \& Schneider, 1990). This may be particularly true for organizational leaders who believe strongly in, and are loyal to the company. It is conceivable that senior managers can see their culture as positive and effective, despite evidence to the contrary. Leaders who 
demonstrate high levels of commitment to the organization and its goals may see themselves as an extension of the organization (Testa, 2001). Subsequently, identifying any negative factors related to the organization can be tantamount to self-criticism. Both self-theory (Snyder \& Williams, 1982) and social identity theory (Ashforth \& Mael, 1989) provide theoretical support for this notion.

Given the need for a strong, focused organizational culture, the question becomes, what specifically needs to be strengthened? Little has been done which helps researchers or senior managers identify organizational culture gaps. More specifically, little has been done which provides a purposeful assessment of the culture using an action research approach, which allows for understanding unique organizational differences. The purpose of the current study is to illustrate how organizational culture assessment can be ambiguous, particularly for senior managers. Next, a theoretical foundation for cultural analysis is provided. Finally, implementation of the culture audit process is discussed using a five-step process, with a ten-category model. This work adds to an early version of this model proposed to hospitality executives. In this expanded work, four primary differences exist. First, a review of cultural ambiguity is provided which provides greater support for the need to accurately assess the true culture. Next, a full section focused on disparities in leader perceptions of organization culture is provided to further support the importance of the audit. In this more complete paper, examples of fieldwork using the model are provided as well. This helps to illustrate the varying ways the audit process may be implemented. Finally, a greater focus on implications of the model is offered to illustrate how its use may impact organizations seeking quality guest experiences. It is hoped that this effort can be used in taking a proactive approach to improving organizational effectiveness as well as a means for diagnosing the source of chronic organizational problems.

\section{Organizational Culture Ambiguity}

In spite of many attempts, there has been no clear consensus about the definition and measurement of organizational culture among researchers and practitioners (Deshpande \& Webster, 1989). Indeed, an early study found no less than 164 varying definitions of culture (Kroeber \& Kluckhohn, 1952, cited in Leidner \& Kayworth, 2006). The ambiguity of culture as a construct is further illustrated by two schools of thought on how to approach culture. Some view the culture as "something the organization has" where others see it as "something the organization is” (Reichers \& Schneider, 1990: p. 22; Smirchich, 1983). In the first instance, culture is used as a variable in the study of antecedents and outcomes. This allows comparison of organizations/cultures based on internal and external variables. In the second approach, the organization and the culture are indistinguishable. This "root metaphor" (Smirchich, 1983) approach is more descriptive in nature and identifies the meaning connected with the culture. Using an anthropological approach, the richness of an organizational culture is identified by shared cognition, shared symbols and unconscious processes (Driskill \& Brenton, 2005). The current study seeks to provide direction based on this school of thought.

Definitions of culture are both numerous and varying. Some definitions simply state the central notion of culture, and others include multiple components. Table 1 provides a summary of the various definitions of culture provided in the research.

Schein (1992) provides the most commonly cited definition of culture and will provide much of the foundation for the culture audit discussed here. Schein defines culture as: "a pattern of shared basic assumptions learned by a group as it solved its problems of external adaptation and internal integration which has worked well enough to be considered valid and therefore, to be taught to new members as the correct way to perceive, think, and feel in relation to those problems” (p. 12).

This definition identifies "assumptions" as the key component of organizational culture. An important message regarding culture is provided by Pettigrew (1990) in his summary of a collection of essays on climate and culture. The author notes that "climate and culture are complex, multidimensional, and multilevel constructs” (p. 421). As such they must be viewed at varying levels. Schein (2004) agrees providing three levels of culture which flow from the more physical to the more cognitive components as shown in Figure 1.

At the first level are organizational artifacts. Artifacts refer to the things one might see, hear or feel when confronted with a new environment and are easily identifiable. For example, a standard guest greeting used by hotel employees or a sign highlighting the importance of guest service may convey standards of conduct. Similarly, the physical environment, layout or climate may indicate what is acceptable or not acceptable in the work environment. Schein (2004) notes that while easily observable, these artifacts may be difficult to decipher. Put simply, symbols can be ambiguous, and subsequently may send mixed messages to the observer. For example, a new employee viewing a manager who follows rules and policies meticulously may only describe him or her as such if past experience allows it. If the employee previously worked at an organization with exceedingly strict rules and policies, he or she may interpret the new environment as lacking. Greater exposure to the culture's deeper levels and use of a variety of artifacts to craft an accurate depiction becomes important to counter ambiguity.

At the next level, Schein (2004) describes collective beliefs or values. Groups learn collectively and begin to create belief systems. For example, if a manager uses technology to counter a difficult scheduling problem, the group may collectively believe that this is the appropriate way to confront such issues. Over time, these beliefs become ingrained in the culture and become both motivational and restrictive. Beliefs can be motivational in the sense that they can drive behavior, and restrictive because they may prevent a greater range of choices or options in solving problems. An interesting conflict may emerge at the belief level when there is a disconnect between what the organization says it believes, and what it actually does. Stated or espoused values are not always in sync with organizational action. For example, a company that says it values customers, but continues to find ways to provide lower product quality or treat employees poorly, may be out of sync. Similar to artifacts, beliefs can sometimes be so broad as to be ambivalent. A look at the assumptions made by the organization helps to clarify the culture.

At the deepest level, organizations make assumptions about how the world works and how it operates within it. These assumptions are created over time and provide behavioral influence. For example, if it is assumed that customer satisfaction is predominantly determined by the technical components of service (i.e., speed of service, efficiency, etc.), the personal side of service quality may be discounted. Further, programs and plans 


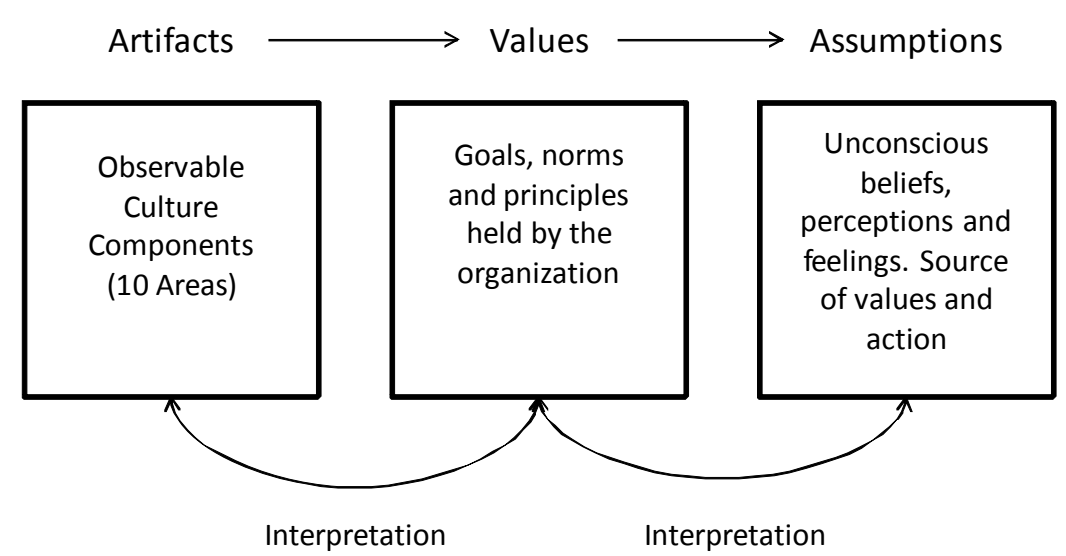

Figure 1.

Culture audit process based on Schein 2004 levels of culture model.

Table 1.

Definitions of organizational culture.

\begin{tabular}{|c|c|}
\hline Author & Definition \\
\hline Rossi \& O’Higgins (1980) & "Culture is a system of shared cognitions or a system of knowledge and beliefs." \\
\hline Hofstede (1980) & $\begin{array}{l}\text { "The collective programming of the mind which distinguishes members of one human group from } \\
\text { another." }\end{array}$ \\
\hline Deal \& Kennedy (1982) & "The way things get done around here." \\
\hline Drennan (1992) & "How things are done around here." \\
\hline House, Wright \& Aditya (1997) & $\begin{array}{l}\text { "Distinctive normative systems consisting of modal patterns of shared psychological properties among } \\
\text { members of collectivities that result in compelling common affective, attitudinal, and behavioral } \\
\text { orientations that are transmitted across generations and that differentiate collectivities from each other." }\end{array}$ \\
\hline Ogbonna \& Lloyd (2002) & $\begin{array}{l}\text { "The collective sum of beliefs, values, meanings and assumptions that are shared by a social group and } \\
\text { that help to shape the ways in which they respond to each other and to their external environment." }\end{array}$ \\
\hline
\end{tabular}

made to increase organizational effectiveness may be greatly influenced. To the extent those assumptions are no longer valid, it becomes easy to see that poor decisions will result. This may be commonplace in an environment with a predominant "way we do it around here" mentality.

It's important to highlight the role of interpretation in this process. One viewing a particular cultural artifact has freedom to determine the corresponding values and assumptions it reveals. Similarly, senior managers have freedom to determine if the current organization culture is the desired organizational culture. Several obstacles may prevent leaders from accurately evaluating this symmetry.

\section{Leader Perceptions of Culture}

Senior managers may have the greatest impact on an organizations' culture. Given their ability to control resources and decide on important organizational initiatives, senior leaders should be responsible for actions taken to craft a particular culture. This presupposes that these leaders see the need for change. Self-based theories share the common assumption that humans have a basic need to protect or improve one's self. This essential motivation may cause highly committed managers to avoid acknowledging negative components of the organizational culture. Both self-theory (ST) (Snyder \& Williams, 1982; Sullivan, 1989) and social identity theory (SIT) (Ashforth \&
Mael, 1989) provide frameworks that might explain how senior managers might lose touch with the true organizational culture.

Self-theory suggests that individuals have a basic need to maintain a positive self-image to protect psychological wellbeing (Snyder \& Williams, 1982; Sullivan, 1989). One may develop a view of the "ideal self." That is, a positive image which includes traits, competencies and values one would ideally possess (Leonard, Beauvais, \& Scholl, 1999). Maintenance of this belief can become a motive for behavior. It is important to note that "self" changes reluctantly. Indeed, the more central a belief, the more likely one is to resist changing that belief. From a leadership standpoint, self-theory may contribute to an inability of some managers to see organizational negatives. For example, a senior manager who has spent considerable time and energy developing an organization is likely to be highly committed to that organization and its goals, and may see his goals as a function of the organizations'. Consequently, such a manager may be protective of the organization just as he would be protective of himself. Seeking to develop the "ideal” image of the organization, he may consciously or unconsciously, defend any attacks on the organization. The result may be an inability to fully accept criticism or constructive feedback in the form of data, survey responses, etc. In an extreme case, rationalization may emerge with the manager seeking to maintain the positive image. 
Difficulty in spotting cultural deficiencies is further supported by social identity theory (SIT) (Ashforth \& Mael, 1989). Social identity theory can be viewed synonymously with group identification. The theory suggests that individuals classify themselves based on the characteristics of the groups in which they belong (Ashforth \& Mael, 1989). Past research indicates that individuals who identify with a particular group (i.e., the organization) feel a strong attraction to the group as a whole (Stets \& Burke, 2000). Consequently, individuals will act in concert with the group. In a practical sense, this suggests that leaders would tend to avoid acting in a way counter to the organization and its needs. Although failing to see negative components of the organization may be harmful in the long-run, a consequence of SIT can be defense of the group and any negativity that threatens it.

Give the potential difficulty leaders may face in confronting organizational culture realities, a process which immerses the leader into the culture as means of assessment may be useful. In addition, such a process may help to counter the challenges of accurately measuring the current culture.

\section{Organizational Culture Assessment}

In addition to ambiguity in defining organizational culture, no clear consensus exists regarding its measurement (Deshpande \& Webster, 1989). Such measurement can be difficult as Lund (2003) points out because shared assumptions reside beneath the conscious level. A variety of questionnaire measures exist attempting to assess culture such as the Organizational Culture Profile (Orielly et al., 1991) and the Organizational Values Congruence Scale (Enz, 1986), but tend to focus primarily on person-organization fit or compatibility. The issue with the person-organization fit model is its focus on individual attitudes towards the organization and does so in a quantitative way. Compatibility with the organization is not the same as a deficiency or failing effort in the organizations culture. The Competing Values Framework (Quinn, 1988) and The Organizational Culture Assessment Instrument (OCAI) (Cameron and Quinn, 1999) allow organizations to go farther in culture analysis than the previous measures. The current version of the assessment determines which of four typologies best describe the organization's culture. These categories are titled Clan, Adhocracy, Hierarchy and Market. In addition, the model will identify the desired culture and allow comparison to the actual culture. The limitation of the assessment is that disparities between desired and actual culture are identified in the context of the four categories and may not be as specific as necessary. Going further, the process does not allow for management involvement in the data collection process. Consequently, identification of deficits and actual change that needs to be addressed outside of the model may be difficult.

Some criticism of questionnaire-based culture measures exists, suggesting that these measures are too similar to job satisfaction measures (Hofstede, 1998; Johannesson, 1973). Surprisingly, little direction is provided in the way of conducting a cultural audit, which would counter the limitations of questionnaire research. An early study by Wilkins (1983) provides some suggestions, but the process cannot be viewed as a managerial tool. Fletcher and Jones (1992) discuss cultural auditing in terms of measurement, and attempt to provide a quantitative formula for comparison. Driskill and Brenton's (2005) work is comprehensive and well-done, but takes an approach which may not be directly suitable in practical application. An assessment that provides a richer analysis of various aspects of the organizational culture may be valuable. The proposed assessment is designed to be broad enough to include varying types of industries, but specific enough to provide useful organizational information.

Given the influence of self-theory previously discussed, seeing the culture as it truly is becomes paramount. The culture audit is an applied method of assessing the synchronicity of these cultural levels and any inconsistencies that might exist. To that end, the goals of the audit are as follows:

1) To examine cultural artifacts and determine their consistency with espoused values and assumptions;

2) To identify conflicts in espoused and actual beliefs and values;

3) To re-examine deeply held assumptions and identify their validity;

4) To develop an action plan for addressing inconsistencies in any of the cultural levels.

\section{The Culture Audit}

The ideal circumstance for conducting a culture audit is the paring of an executive team and organizational development researcher. The uniqueness of the current model is the ability to link theory and practice in a very experiential way. While the executive team can engage in much of the data collection, the researcher can guide their efforts, minimize bias and ensure the generated results are valid. A five-step model was developed for implementation of the culture audit with this executive team-researcher tandem in mind. These steps include:

1) Identification of the organization's vision, mission, values, and strategic goals;

2) A brief narrative on the desired culture;

3) Selection of the audit team;

4) Data collection;

5) Interpretation and reporting.

\section{Step 1: Vision, Mission, Values and Strategic Goals}

The first step in the audit process is to clearly state where the organization is going and how it plans to get there. Clearly articulating vision, mission, values and goals will identify any inconsistencies at the strategic level. Further, statement of these important concepts will provide some direction for the type of culture necessary for their accomplishment. For example, an organization desiring to provide the highest levels of customer service, or values employees and customers, must have a culture that supports these notions. In the study of organizational culture, the context in which the culture operates may be critical for understanding both its strengths and weaknesses. A current overview of key organizational metrics and the "story" behind the organization may be useful as well.

\section{Step 2: Culture Narrative}

The focus of the culture audit is to identify disparities in the organizational culture. That is, to identify areas that are not in sync with the desired culture. Therefore, an initial step must be a clear description of the desired culture. The value of the executive team in this process becomes evident their collective sense becomes the ultimate goal of the process. Whether or not to include other layers or departments in this process are 
dependent on the particular circumstance confronted by the researcher. A variety of questions may be asked which will help to illustrate important organizational values. For example: tion?

1) How do you want your employees to view the organiza-

2) How do you want customers to view the organization?

3) What "feeling" do you want to permeate throughout organization? for?

4) What stories best represent what this organization stands

5) Who are the legendary leaders in this organization and what do they represent?

The narrative should be long enough to convey important values and beliefs, but short enough that stakeholders can grasp the most important components of the culture. This description will provide the comparison necessary to identify any potential gaps in the culture.

\section{Step 3: Selection of the Audit Team}

To identify cultural deficits, using an executive team from varying areas of the organization would be ideal. The goal of the audit is to search for the meaning behind the artifacts, symbols, policies, practices, etc., that make up the organizational culture. Given the limitations of self-theory as previously discussed, implementing methods to ensure objectivity becomes critical. Using leaders from accounting, operations, HR, sales and marketing, etc., may be useful by allowing for multiple view points and prevent the emergence of groupthink. Similarly, using a group of both new and long-tenured leaders may be valuable depending on the specific needs of the organization under review.

\section{Step 4: Data Collection}

A variety of methods focusing on a variety of areas should be used to collect the data for the culture audit. Taking a patchwork approach, researchers should not rely on one or two pieces of information to assess the culture, but should examine multiple aspects over multiple instances from multiples sources. This could include employee interviews, manager interviews, customer interviews and focus groups. To assess the physical artifacts of the culture, focused walk-throughs and physical plant reviews would be useful. To capture deeper components of the culture, observation of employee-employee, employeecustomer, and employee-leader interactions would be revealing. Finally viewing various documents such as training manuals, orientation manuals, standard operating procedures may provide insight.

In the current model, ten areas of culture analysis are recommended. Table 2 provides a comprehensive list of the culture areas, questions to ask and specific aspects to review.

Each area of analysis listed is a common element of an organizational culture as described in past research (Driskill \& Brenton, 2005; Kotter \& Heskett, 1992; Schein, 2004). Each area of the analysis is the foundation of a gaps analysis between the stated or desired organizational culture (i.e., the narrative) and the actual organizational culture. Through a variety of observations, leaders are able to compare the two, and draw conclusions regarding the actual state of the organizational culture.

\section{Step 5: Interpretation and Reporting}

The final step in the audit process is to interpret the data col- lected. At face value, this may seem a direct process. However, given the potential bias that can result during such a process (see Woodman \& Wayne, 1985 for a review), care must be taken in drawing conclusions regarding the results. Again, using a trained researcher in this process may prevent such bias from occurring. First, results of the observation can be placed into summary worksheets. Table 3 provides an example of such a worksheet.

This can be completed by the entire executive team or by sub-teams based on unique knowledge, interest, etc. The goal of the analysis is to draw down on values and assumptions that are revealed through the process. That is, the meaning behind the observations is the important factor rather than the observations themselves. To ensure objective and thorough results, several factors should be considered:

1) Combinations of observed elements to form consistent themes should be used. Rather than focusing on a single observation or example, multiple examples from various sources would help to identify patterns in the culture. These patterns or themes provide the basis for identifying beliefs and assumptions.

2) Both positive and negative observations should be utilized to form themes. Often, negative examples can be more revealing then positive examples. Disconnects between desired cultural artifacts and observed artifacts help to create a shared sense of reality and the organizations true state.

3) Themes should be discussed in a group setting with no judgments. Members of the audit team must be able to honestly reveal their interpretation with no threat of criticism or retaliation. A group dialogue that allows for connections among the observers is desirable.

4) Telling stories rather than revealing facts may be valuable. Stories help to provide linkages in a thorough and compelling way. In addition, stories help to reveal deep dimensions of the culture such as values and assumptions. Stories provide a pathway for revealing the true story behind the culture.

5) Conflicts between artifacts and beliefs, as well as conflicts between espoused values and actual organizational action should be identified. These conflicts can form the basis of actions that should be taken to strengthen the culture.

6) Values and assumptions should be identified by the themes that emerge. The ability to take the analysis to the root level as discussed by Schein (1992) will be a measure of the success of the audit. In addition, the validity of these assumptions should be questioned. Are the assumptions still valid or have they been negated by innovation or changes in the marketplace?

7) Findings should be used to take action. Once the results have been discussed and deciphered, the critical next step is to act based on the findings. The categories used in the culture analysis can also be used as a model for such action planning.

\section{Field Work}

To date, the culture audit has been used exclusively in the educational setting in both graduate and executive education. In the graduate setting, a recent group of 12 Master's students were asked to follow the five-step model and assess their own organization. These organizations ranged from three-person small businesses to major organizations. A variety of job-situations confronted the students from new hires, to those on the verge of leaving the organization. In each circumstance the student was able to successfully apply the model and identify 
Table 2.

Areas of cultural analysis.

\begin{tabular}{|c|c|c|c|}
\hline & Culture Category and Questions & Author & What to Look For \\
\hline 1 & $\begin{array}{l}\text { Physical Characteristics and General } \\
\text { Environment (F-O-H vs B-O-H) } \\
\text { What do the physical components of the organization say } \\
\text { about the culture? } \\
\text { Is there consistency behind the scenes? } \\
\text { How does it feel? } \\
\text { Are employee and customer needs considered in the } \\
\text { planning? Layout? Design? }\end{array}$ & $\begin{array}{l}\text { Hatch (1993) } \\
\text { Hatch \& Schultz (1997) } \\
\text { Schein (1992, 2004) }\end{array}$ & $\begin{array}{ll}\text { - } & \text { Signage (quantity and style) } \\
\text { - } & \text { Furniture and accessories } \\
\text { - } & \text { Tradition vs modern } \\
\text { - } & \text { Symbolors } \\
\text { - } & \text { Lighting logos } \\
\text { - } & \text { Sounds, level and type } \\
\text { - } & \text { Uniforms } \\
& \text { Cleanliness and organization }\end{array}$ \\
\hline 2 & $\begin{array}{l}\text { Customs \& Norms } \\
\text { What regular behaviors and expectations are in place that } \\
\text { affect the culture? } \\
\text { What impact do these have on the culture? } \\
\text { Are guest needs a norm? } \\
\text { Is facilitation of employee needs a norm? }\end{array}$ & $\begin{array}{l}\text { Farrell (2005) } \\
\text { Hallett (2003) } \\
\text { Schein (1992, 2004) }\end{array}$ & $\begin{array}{l}\text { - } \text { Greetings } \\
\text { - } \quad \text { Language \& phrases } \\
\text { - } \quad \text { Commoctations set by leadership } \\
\text { - } \quad \text { Commonon leader-employee interactions } \\
\text { - } \quad \text { Common leader/employee-guest intens } \\
\text { - } \quad \text { Unspoken rules } \\
\text { Uniforms norms }\end{array}$ \\
\hline 3 & $\begin{array}{l}\text { Ceremonies \& Events } \\
\text { What is systematically celebrated and recognized at this } \\
\text { organization? } \\
\text { Are service champions recognized? } \\
\text { What impact does this have on the culture? }\end{array}$ & $\begin{array}{l}\text { Hatch (1993) } \\
\text { Schein }(1992,2004) \\
\text { Trice \& Beyer (1984) }\end{array}$ & 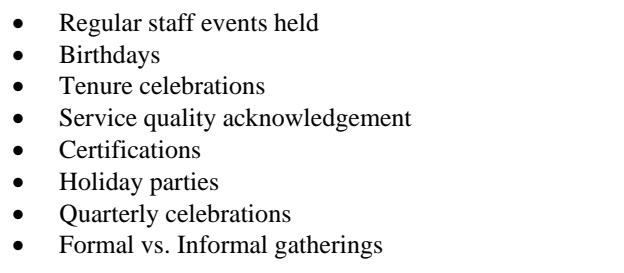 \\
\hline 4 & $\begin{array}{l}\text { Rules \& Policies } \\
\text { How formalized is organization? } \\
\text { Is the culture more rule-based or empowering? } \\
\text { Does it strike a balance? } \\
\text { Are rules and polices absolutes or guidelines? } \\
\text { Are guest/employee needs balanced with policies? }\end{array}$ & $\begin{array}{l}\text { Farrell (2005) } \\
\text { Hallett (2003) } \\
\text { Schein }(1992,2004)\end{array}$ & 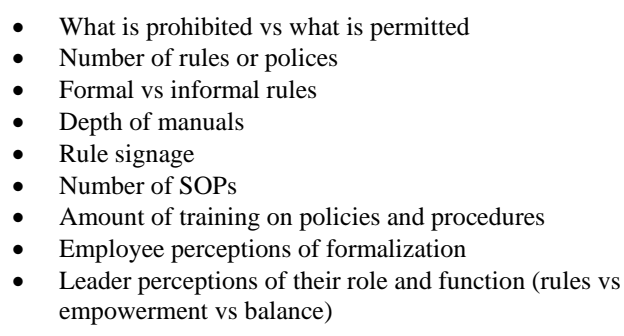 \\
\hline 5 & $\begin{array}{l}\text { Measurement \& Accountability } \\
\text { What gets measured in this organization? } \\
\text { What measures are most important? } \\
\text { Is there accountability? } \\
\text { Are measurements consistent with vision, mission, } \\
\text { values? } \\
\text { Are guest and employee needs central to } \\
\text { measurement? }\end{array}$ & $\begin{array}{l}\text { Hallett (2003) } \\
\text { Schein }(1992,2004)\end{array}$ & $\begin{array}{ll}\text { - } & \text { Types of measures used } \\
\text { - How senior leaders, supervisors and employees are } & \text { evaluated } \\
\text { - } & \text { Measures vs espoused Values } \\
\text { - } & \text { Promotion criteria } \\
\text { - } & \text { Dismissal criteria } \\
& \text { Discipline system }\end{array}$ \\
\hline 6 & $\begin{array}{l}\text { Leader Behavior } \\
\text { What do leaders make a priority here? } \\
\text { Are leaders at varying levels role models? } \\
\text { Do these leaders role model guest service behaviors? } \\
\text { Which leaders are most respected here and why? } \\
\text { How does this impact the culture? }\end{array}$ & $\begin{array}{l}\text { Bass \& Avolio (1993) } \\
\text { Schein (1992, 2004) } \\
\text { Tusi et al. }(2006)\end{array}$ & $\begin{array}{ll}\text { - } & \text { Leader focus task vs people } \\
\text { - } & \text { Leader-employee interactions } \\
\text { - } & \text { Leader-guest interactions } \\
\text { - } & \text { Legendaee perceptions of leadership } \\
\text { - } & \text { Outlaw leaders }\end{array}$ \\
\hline 7 & $\begin{array}{l}\text { Rewards \& Recognition } \\
\text { What gets rewarded in this organization? How are } \\
\text { employees recognized for their efforts? } \\
\text { How does this impact the culture? }\end{array}$ & $\begin{array}{l}\text { Bushardt, Lambert, \& } \\
\text { Duhon (2007) } \\
\text { Milne (2007) } \\
\text { Schein (1992, 2004) }\end{array}$ & 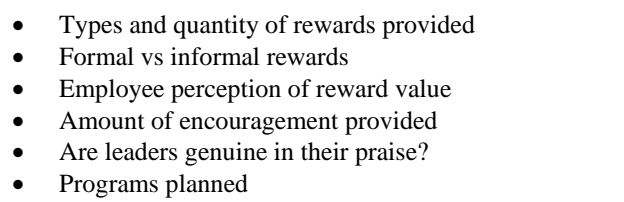 \\
\hline
\end{tabular}




\section{Training \& Development}

What efforts are made to invest in human resources?

8 What impact do these efforts have on the culture? Does the discipline system promote guest and employee needs?

\section{Communication}

How are messages, both formal and informal communicated?

9 What is the impact on the culture?

What do stories told in this organization reveal? Are guests/employees valued or criticized in the stories told.

\section{Structure and Culture Development Efforts}

How is the organization structured?

Does the organizational structure (hierarchy) impact the culture?

10 How quickly are decisions made?

Are employees empowered to solve guest problems rapidly?

Does the organization actively work towards developing its culture?
- Amount and types of training

- Certifications

- On-the-job vs formal

Bunch (2007)

Kissack \& Callahan (2010)

- Orientation processes

- Service quality vs rule based efforts/technical

- Leadership development programs

- Succession planning

- How do employees find things out?

- Email vs memos vs signage vs face-to-face

- Number and type of meetings

- Senior leader communication

- $\quad$ Are the methods effective?

- Are the methods appropriate?

- Is confidentiality ensured

- How much do employees find out through the grapevine?

- Metaphors used

- Layers on the organizational chart

- Formal are the chains of command

- Disconnects between the top and bottom of the structure

Hallett (2003)

Schein $(1992,2004)$

Smircich (1983)

unication barriers

- Vision, mission, values, goal consistency

- Senior leader activities to build the culture

- Employee perception of culture development efforts

- Employee view the culture

organizational culture gaps. This required some flexibility in the approach; however the validity of the model at face value seemed apparent. Although the specific findings of each investigation are beyond the scope of this paper, the ability to actively engage organizational stakeholders was valuable in identifying the true organizational culture and subsequent gaps.

In similar fashion, the culture audit was used successfully with two groups of 30 senior leaders in the attractions industry. As part of a five-day executive education program, the executives were asked to conduct an audit of a local attraction and report back to management on their findings. In this case, the cultural narrative came after the audit to be used as a comparison to the findings. This removed any bias that might emerge after the desired culture was identified. Working in three-person teams, the executives spent a full-day at the attraction engaging staff, observing interactions, assessing front and back areas, and speaking with departmental leaders. Again, at face value, the audit appears to provide a means for identifying some cultural gaps. While further study is required, these preliminary findings are encouraging.

\section{Implications}

The intangible, co-constructed nature of the customer experience makes measuring business performance difficult, particularly where stakeholder and customer interactions take place (Gallouj, 2002). The culture audit provides an opportunity to assess business performance beyond guest satisfaction ratings or financial metrics. The model presented here allows managers to examine how the product is delivered in their organization as well as what the customer observes. Essentially, it provides an opportunity to blend assessment of what the guest experiences with what the employee experiences. Given the linkage and interdependence of the two groups, this may be very valuable. In addition, the cultural audit process provides an opportunity for managers to practice making rounds of their organizations with the sole purpose of enhancing organizational culture. The structure of the audit provides a focus that goes beyond just "management by walking around" or empty face time. It is similar to the notion of "rounding for outcomes" introduced by the health care industry. Much like physicians make patient rounds, the leading healthcare organizations encourage the rounding for outcomes process as a way to encourage managers to focus on the positive with their employees (Studer, 2003). Having a plan when making rounds has become common practice for senior leaders in healthcare and is cited by some as critical to improvements in both patient and employee satisfaction scores (Hotko, 2004). The cultural audit offers a structured approach to purposeful rounding for organizational leaders.

Finally, the result of the audit process should be a greater understanding of the true organizational culture. Leaders seeking to deliver the highest levels of service or maximizing guest experiences have a critical need for such an understanding. Simply put, leaders can make better decisions regarding their organization, operations, and various stakeholders when more complete information is available. An audit as described here can help in this regard. Going farther, regardless of the outcomes, the audit process itself may be seen positively by employees. By actively engaging employees to identify their perceptions, challenges, successes and failures, the culture itself is positively impacted. Indeed, the dialogue that emerges moves the organization closer to its vision.

\section{Conclusion}

The purpose of this study was to illustrate how organizational culture can be an ambiguous construct and show why leaders may have difficulty identifying their true culture. In addition, this study provides a theoretical foundation for, and 
Table 3.

Audit summary sheet example.

\begin{tabular}{lll}
\hline \multicolumn{1}{c}{ Culture Category } & \multicolumn{1}{c}{ What to Look For } \\
\hline Physical Characteristics and General Environment & $\bullet$ Signage (quantity and style) \\
(F-O-H vs B-O-H) & - Furniture and accessories \\
What do the physical components of the organization say & $\bullet$ Colors \\
about the culture? & $\bullet$ Symbols \& logos \\
Is there consistency behind the scenes? & $\bullet$ Lighting \\
How does it feel? & - Sounds, level and type \\
Are employee and customer needs considered in the & Uniforms \\
planning? Layout? Design? & $\bullet$ Cleanliness and organization
\end{tabular}

Actions to Be Taken:

Customs \& Norms

What regular behaviors and expectations are in place that

2 affect the culture?

What impact do these have on the culture?

Are guest needs a norm?

Is facilitation of employee needs a norm?
- Greetings

- $\quad$ Language \& phrases

- Expectations se by leadership

- Common employee interactions

- Common leader-employee interactions

- Common leader/employee-guest interactions

- Unspoken rules

- Uniforms norms

Actions to Be Taken:

practical means to, conducting an organizational culture audit to counter these issues. It seems clear that a compelling culture would be beneficial in gaining competitive advantage. In an effort to craft such a culture, an action research model is proposed which should allow leaders and their executive committees to conduct a thorough assessment of their culture. By identifying deficiencies or gaps, action may be taken to strengthen the culture. In addition, this process may be valuable in that it stimulates dialogue among the executive team. Using an action research approach, this process facilitates discussion among the key decision makers regarding both the desired and actual culture. It is hoped the direction provided here is useful for researchers seeking a deeper assessment of culture, particularly in the field setting, however several limitations exist.

First, cultural auditing can be a very complex task and one that requires careful application. This model may simplify the process, but caution must be used in both the data collection and the interpretation. Next, while many areas of organizational culture are provided here, the model may not be useful for all organizations as is. Every culture is different and there may be additional areas of analysis that should be included. This study should however provide an adequate starting point for varying types of organizations. Next, further study of, and application of the model is required. While some face validity is provided from the field work described here, more rigorous testing is needed.

Finally, the literature on organizational culture is vast. While mainstay authors and studies have been included, an expanded version of this model can pay greater attention to components of culture assessment that could not be addressed here.

\section{REFERENCES}

American Customer Satisfaction Index (2011). ACSI commentary June 2011.

http://www.theacsi.org/index.php?option=com_content\&view=articl e\&id=256:acsi-commentary-june-2011\&catid=14\&Itemid=335
Ashforth, B. E., \& Mael, F. (1989). Social identity theory and the organization. Academy of Management Review, 14, 20-39.

Bass, B. M., \& Avolio, B. J. (1993). Transformational leadership and organizational culture. Public Administration Quarterly, 17, 112121.

Birnbaum, D., \& Sommers, M. J. (1986). The influence of occupational image subcultures on job attitudes, job performance, and the job attitude-job performance relationship. Human Relations, 39, 661-672. doi:10.1177/001872678603900705

Bunch, K. (2007). Training failure as a consequence of organizational culture. Human Resource Development Review, 6, 142-163. doi:10.1177/1534484307299273

Bushardt, S. C., Lambert, J., \& Duhon, D. L. (2007). Selecting a better carrot: Organizational learning formal rewards and culture-A behavioral perspective. Journal of Organizational Culture, Communication and Conflict, 11, 67-79.

Cameron, K. S., \& Quinn, R. E. (1999). Diagnosing and changing organizational culture. New York, NY: Addison Wesley.

Denison, D. R., \& Mishra, A. K. (1995). Toward a theory of organizational culture and effectiveness. Organizational Science, 6, 204-223. doi:10.1287/orsc.6.2.204

Deshpande, R. \& Webster, F. E. (1989). Organizational culture and marketing: Defining the research agenda. Journal of Marketing, 53, 3-15. doi:10.2307/1251521

Drennan, D. (1992). Transforming company culture. London: McGrawHill.

Driskill, G.W., \& Brenton, A. L. (2005). Organizational culture in action: A cultural analysis workbook. Thousand Oaks: Sage Publications.

Enz, C. A. (1986). Power and shared values in the corporate culture. Ann Arbor: UMI Research Press.

Farrell, M. A. (2005). The effect of market-oriented organisational culture on sales-force behavior and attitudes. Journal of Strategic Marketing, 13, 261-273. doi:10.1080/09652540500338295

Fletcher, B., \& Jones, F. (1992). Measuring organizational culture: The cultural audit. Managerial Accounting Journal, 7, 30-36. doi:10.1108/eb017606

Freiberg, K. \& Freiberg, J. (1997). Nuts! Southwest Airlines' crazy recipe for business and personal success. New York, NY: Broadway Books.

Gallouj, F. (2002). Innovation in services and the attendant old and new myths. Journal of Socio-Economics, 31, 137-154. 
doi:10.1016/S1053-5357(01)00126-3

Hallett, T. (2003). Symbolic power and organizational culture. Sociological Theory, 21, 128-149. doi:10.1111/1467-9558.00181

Hatch, M. J. (1993). The dymanics of organizational culture. The Academy of Management Review, 18, 657-693.

Hatch, M. J., \& Schultz, M. (1997). Relations between organizational culture, identity and image. European Journal of Marketing, 31, 356365. doi:10.1108/eb060636

Hofstede, G. (1980). Motivation, leadership, and organization: Do American theories apply abroad? Organizational Dynamics, 9, 42-58. doi:10.1016/0090-2616(80)90013-3

Hofstede, G. (1988). Attitudes, values and organizational culture: Disentangling the concepts. Organization Studies, 19, 477-492. doi:10.1177/017084069801900305

Hotko, B. (2004). Rounding for outcomes. Studer Group Newsletter, 1, 1.

House, R. J., Wright, N., \& Aditya, R. N. (1997). Cross-cultural research on organizational leadership: A critical analysis and a proposed theory. In P. C. Earley, \& M. Erez (Eds.), New perspectives on international/organizational psychology (pp. 535-625). San Francisco: New Lexington.

Kemp, S., \& Dwyer, L. (2001). An examination of organizational culture-The Regent Hotel, Sydney. International Journal of Hospitality Management, 20, 77-93. doi:10.1016/S0278-4319(00)00045-1

Kissack, H. C., \& Callahan, J. L. (2010). The reciprocal influence of organizational culture and training and development programs. Journal of European Industrial Training, 34, 365-380.

doi:10.1108/03090591011039090

Kotter, J. P., \& Heskett, J. L., (1992). Corporate culture and performance. New York: Free Press.

Leonard, N. H., Beauvais, L. L., \& Scholl, R. W. (1999). Work motivetion: The incorporation of self-concept-based processes. Human Relations, 52, 969-998. doi:10.1177/001872679905200801

LeBlanc, C. L., \& Mills, K. E. (1995). Competitive advantage begins with positive culture. Nation's Restaurant News, 29, 22-24.

Leidner, D. E., \& Kayworth, T. (2006). Review: A review of culture in information systems research: Toward a theory of information technology culture conflict. MIS Quarterly, 30, 357-399.

Lund, D. (2003). Organizational culture and job satisfaction. Journal of Business \& Industrial Marketing, 18, 219-236. doi:10.1108/0885862031047313

Milne, P. (2007). Motivation, incentives and organisational culture. Journal of Knowledge Management, 11, 28-38. doi:10.1108/13673270710832145

Ogbonna, E., \& Lloyd, C. H. (2002). Managing organizational culture: Insights from the hospitality industry. Human Resource Management Journal, 12, 33-53. doi:10.1111/j.1748-8583.2002.tb00056.x

O’Reilly, C. A., Chatman, J. A., \& Caldwell, D. F. (1991). People and organizational culture: A profile comparison approach to assessing person-organization fit. Academy of Management Journal, 34, 487516. doi:10.2307/256404

Quinn, R. E. (1988). Beyond rational management. San Francisco, CA: Jossey-Bass.

Reichers, A. E., \& Schneider, B. (1990). Climate and culture: An evo- lution of constructs. In B. Schneider (Ed.), Organizational climate and culture (pp. 5-39). San Francisco: Jossey-Bass.

Reichfield, F., \& Sasser, W. (1990). Zero defections: Quality comes to customer service. Harvard Business Review, 68, 105-111.

Savit, M. (2012). Above and beyond. Lodging Magazine, 37, 42-44.

Schein, E. (1992). Organizational culture and leadership (2nd ed.). San Francisco, CA: Jossey-Bass.

Schein, E. (2004). Organizational culture and leadership (3rd ed.). San Francisco, CA: Jossey-Bass.

Smircich, L. (1983). Concepts of culture and organizational analysis. Administrative Science Quarterly, 28, 339-358. doi:10.2307/2392246

Snyder, R. A., \& Williams, R. R. (1982). Self-theory: An integrative theory of work motivation. Journal of Occupational Psychology, 55, 257-267. doi:10.1111/j.2044-8325.1982.tb00099.x

Stets, J. E., \& Burke, P. J. (2000). Identity theory and social identity theory. Social Psychology Quarterly, 63, 224-237. doi:10.2307/2695870

Studer, Q. (2003). Hardwiring excellence: Purpose, worthwhile work, making a difference. Gulf Breeze, FL: Fire Starter Publishing.

Sullivan, J. J. (1989). Self theories and employee motivation. Journal of Management, 15, 345-363.

Testa, M. R. (2001). Hospitality leaders: Do they know how their employees feel about them? Cornell Hotel and Restaurant Administration Quarterly, 42, 80-89.

Tidball, K. H. (1988). Creating a culture that builds your bottom line. Cornell Hotel and Restaurant Quarterly, 29, 63-69. doi: $10.1177 / 001088048802900118$

Trefry, M. G. (2006). A double-edged sword: Organizational culture in multicultural organizations. International Journal of Management, 23, 563-575.

Trice, H. M., \& Beyer, J. M. (1984). Studying organizational culture through rites and ceremonials. Academy of Management Review, 9, 653-669.

Trice, H. M., \& Beyer, J. M. (1993). The cultures of work organizations. Englewood Cliffs, NJ: Prentice Hall.

Tsui, A. S., Zhang, Z. X., Wang, H., Xin, K. R., \& Wu, J. B. (2006). Unpacking the relationship between CEO leadership behavior and organizational culture. The Leadership Quarterly, 17, 113-137. doi:10.1016/j.leaqua.2005.12.001

Ueno, A. (2010). What are the fundamental features supporting service quality? Journal of Services Marketing, 24, 74-86.

Woodman, R. W., \& Wayne, S. J. (1985). An investigation of positive-findings bias in evaluation of organization development interventions. Academy of Management Journal, 28, 889-913. doi: $10.2307 / 256243$

Wilkins, A. L. (1983). The culture audit: A tool for understanding organizations. Organizational Dynamics, 12, 24-39. doi:10.1016/0090-2616(83)90031-1

Xenikou, A., \& Simosi, M. (2006). Organizational culture and transformational leadership as predictors of business unit performance. Journal of Managerial Psychology, 21, 566-579.

doi:10.1016/0090-2616(83)90031-1 